\title{
Floristic Composition and Structure in Relation to Elevation in the Togo Plateau Forest Reserve in Ghana
}

\author{
Gilchrist K. Faith Dogor, Emmanuel Acquah, and Alexander K. Anning
}

\section{ABSTRACT}

Plateau ecosystems are of special scientific and conservation interests as they harbour rich plant diversity and exhibit considerable spatial variability along elevation gradients. In this study, variations in floristic composition and structure in relation to elevation were studied in six-fringed communities Hohoe (HH), Alavanyo (AL), Santrokofi (SA), Akpafu (AK), Bowuri (BO), and Nkonya (NK) of the Togo Plateau Forest Reserve in Ghana to help provide explicit and effective management of this ecological hotspot. A total of 180 plots (each measuring $25 \mathrm{~m} \times 25 \mathrm{~m}$ ) were demarcated across the six communities for sampling of trees (DBH measured at $1.3 \mathbf{~ m}$ above ground $\geq 10 \mathrm{~cm}$ ). Smaller nested plots, measuring $5 \mathrm{~m} \times 5 \mathrm{~m}$ and $1 \mathrm{~m} \times$ $1 \mathrm{~m}$, were used for sampling saplings (DBH $<10 \mathrm{~cm}$, height $>1.5 \mathrm{~m})$ and seedlings (DBH $<3 \mathrm{~cm}$, height $<1.5 \mathrm{~m}$ ), respectively. Species identity and abundance and elevation were recorded for each plot. Relationships of elevation gradient with vegetation attributes were analysed using simple linear regression. A total of 281 plant species (164 trees, 60 saplings and 57 seedlings) belonging to 66 families were recorded in the study. Leguminosae, Apocynaceae and Euphorbiaceae were the most dominant families across and along the elevation gradient. Average basal area of trees across the six communities was $44.72 \mathrm{~m}^{2} / \mathrm{ha}$ (ranged from $57.10 \mathrm{~m}^{2} / \mathrm{ha}$ at $\mathrm{BO}$ to $33.10 \mathrm{~m}^{2} / \mathrm{ha}$ at $\mathrm{AL}$ ) whereas the Shannon-Weiner Index (H') averaged 3.99 (ranged from $4.14 \mathrm{~m}^{2} / \mathrm{ha}$ at $\mathrm{BO}$ to $3.89 \mathrm{~m}^{2} / \mathrm{ha}$ at $\mathrm{AL}$ ) and evenness index averaged 0.96 (ranged from 1.00 at $\mathrm{BO}$ to 0.92 at $\mathrm{AL}$ ). The saplings and seedlings showed a similar pattern of composition and structure as the trees. The geographical locations of the study communities, which somehow correspond with different elevations of the plateau (i.e., BO, NK occur in lower elevations, $\mathrm{SA}, \mathrm{AL}$ in mid elevations and $\mathrm{HH}, \mathrm{AL}$ in higher elevations), was observed to have marginally influenced the composition and structure of the vegetation on the landscape. The most important trees listed in the study were Ceiba pentandra, Albizia zygia, and Terminalia superba. The saplings were Acacia camerunensis, Microdesmis puberula and Cnestis ferruginea. The seedlings were Chromoleana odorata, Palisota hirsuta and Costus affer. The most important tree species listed were distributed along a broad range of elevations. These results generally demonstrate the high floristic diversity of the Topo Plateau and the influence of elevation gradient on this, which should help in understanding of the composition and structure of several plateau ecosystems in Ghana and elsewhere.

Keywords: Togo Plateau Forest Reserve, Plateau ecosystem, Elevation gradient, Plant diversity.

\section{INTRODUCTION}

Plateau forests are one of the most ecologically complex and biologically rich ecosystems in the world [1]-[5]. These ecosystems provide a series of elevation gradients that drive the patterns of species composition and structure [6]-[8]. Plateaus are known to play a vital role in supporting life of communities fringing it, in particular, and the planet as a whole [6], [9], [10]. They provide many ecosystem services which can be grouped as supporting services (soil formation, nutrient cycling), provisioning services (food, wood, water), regulation services (water regulation, climate regulation, land degradation) and cultural services (recreational,
Published Online: December 28, 2020 ISSN: 2684-5199

DOI:10.24018/ejbio.2020.1.6.133

Gilchrist K. Faith Dogor*

Department of Theoretical and Applied Biology, College of Science, Kwame Nkrumah University of Science and Technology, Ghana.

(e-mail: gilchristdogor@gmail.com) Emmanuel Acquah

Department of Forest Resources Technology, College of Agriculture and Natural Resources, Kwame Nkrumah University of Science and Technology, Ghana.

Alexander K. Anning

Department of Theoretical and Applied Biology, College of Science, Kwame Nkrumah University of Science and Technology, Ghana.

*Corresponding Author consciousness, religion) [9]-[11].

Despite their importance, available data suggest a steady decline in biodiversity from these unique ecological units [9], [10], leading to calls for their conservation [4], [6], [12]. Ecologists have also predicted a $0.2 \%$ loss of plateau ecosystems each year, particularly in Africa, Amazonia, and parts of South-East Asia, should the current rate of degradation continue [10], [12]. Further, the existing gaps in knowledge concerning the composition and structure of plateau ecosystems [14], [13], make it difficult to comprehend their function, conservation, and transformations, particularly with elevation and climate [12], [13]. Understanding the composition and structure of these 
ecosystems and their drivers as well as managing them sustainably require more floristic surveys at a variety of scales [10], [12]. Several factors drive vegetation composition and structure of plateau ecosystems, of which elevation is one of the most well documented [10], [12]. Elevation plays an important role in controlling the ecological and physiological adaptations of various growth forms of plants [7], [14]. These are often accomplished through its regulatory role in the spatial and temporal distribution of climatic factors such as solar radiation, soil formation processes, precipitation, temperature, resource availability, soil organic matter and carbon storage [12], [15]. As a consequence, species diversity has been observed to increase with altitude until mid-elevations and then decrease in tropical forests [6], [16].

The Togo Plateau Forest Reserve is considered a rich biodiversity hotspot, having diverse species of flora and fauna. The plateau covers a total forest area of 14.763 hectares and stretches from Volta Region to Oti Region in Ghana. The reserve is characterized by horizontal layers of sedimentary rocks, a wide range of elevation, hundreds of escarpment and rocky mountain provinces. Its high topographic complexity has created different life zones that support different vegetation communities. The plateau, therefore, provides a good ecosystem for evaluating the relationship between species composition and structure and elevation [3], [7], but to the best of our knowledge, no scientific quantitative studies have been documented for this ecosystem. Consequently, its ecological needs and major threats are poorly understood, and the conservation requirements of this area are not appreciated [3], [7]. This dearth of scientific information presents a major limitation for effective management and conservation of the reserve.

This study investigates the floristic composition and structure of the Togo Plateau Forest Reserve in Ghana in relation to elevation. Generally, the study is expected to help elucidate the current state of the vegetation and provide the critical baseline floristic information for effective conservation planning and management of this plateau ecosystem. The study addresses two key questions: a) what is the floristic composition and structure of the Togo Plateau Forest Reserve? and b) how do the composition and structure of the plateau ecosystem change along the elevational gradient across the different fringed-communities? Elevation was expected to drive the patterns in species composition and structure in the communities around the TPFR in Ghana.

\section{MATERIALS AND METHODS}

\section{A. Description of the Study Area}

The Togo Plateau Forest Reserve (longitude $0^{\circ} 15^{\prime} \mathrm{E}$ and $0^{\circ}$ $45^{\prime} \mathrm{E}$ and latitude $6^{\circ} 45^{\prime} \mathrm{N}$ and $7^{\circ} 15^{\prime} \mathrm{N}$ ) is surrounded by several communities. These communities include Hohoe and Alavanyo in the Hohoe municipality of the Volta Region, as well as Santrofi and Akpafu in the Jasikan District and Bowuri and Nkonya in the Biakoye District in the Oti Region, all in the Republic of Ghana (Fig. 1). The geographical locations of the study communities to the plateau somehow correspond with different elevations (i.e., BO, NK occur in lower elevations, $\mathrm{AK}, \mathrm{SA}$ in mid elevation and $\mathrm{HH}, \mathrm{AL}$ in higher elevations). The reserve, which covers an area of 14.76 hectares, was established by the British Colonial Administration in 1929 and gazetted in 1931 as a national reserve. The reserve lies in the wet semi-equatorial climatic zone and receives an average annual rainfall of between 1016 and $1210 \mathrm{~mm}$. The dry season lasts 4-5 months and occurs between November and April. Temperatures are high throughout the year and range from $26^{\circ} \mathrm{C}$ to $32^{\circ} \mathrm{C}$ [29].

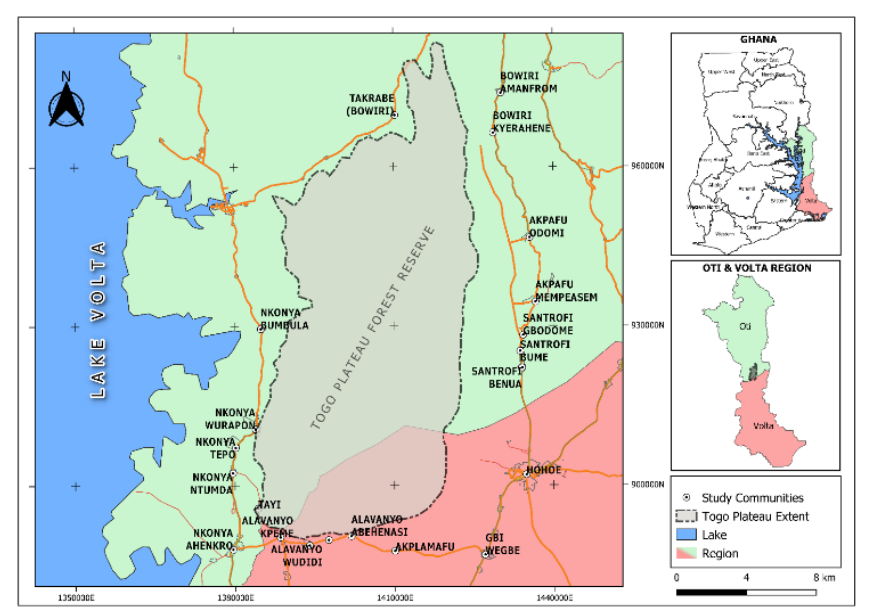

Fig. 1. The Togo Plateau Forest Reserve in the Volta and Oti Regions of Ghana showing the locations of the study communities.

\section{B. Floristic Assessment}

Six Communities (Hohoe, Alavanyo, Santrokofi, Akpafu, Bowuri and Nkonya) fringing the Togo Plateau Forest Reserve in Ghana, were selected for the study. Thirty plots (each of dimension $25 \mathrm{~m} \times 25 \mathrm{~m}$ ) were demarcated in each of the six communities $(n=180)$ for sampling of trees. Plots were laid out perpendicular to the slope contours of the plateau (Fig. 1). In each plot, all trees (i.e., diameter at breast height, $\mathrm{DBH}$, measured at $1.3 \mathrm{~m}$ above ground $\geq 10 \mathrm{~cm}$ ) were identified and their DBH determined using a diameter tape. Plot elevations were recorded for all plots using the Global Positioning System (GPS, Garmin GPS-62). Smaller nested plots, measuring $5 \mathrm{~m} \times 5 \mathrm{~m}$ and $1 \mathrm{~m} \times 1 \mathrm{~m}$ were used to sample saplings (DBH $<10 \mathrm{~cm}$, height $>1.5 \mathrm{~m}$ ) and seedlings (DBH $<3 \mathrm{~cm}$, height $<1.5 \mathrm{~m}$ ), respectively. Plant identification was done with the help of a plant taxonomist and a local specialist, and the names were verified from the online resource, The Plant List (2013). Sampling was done between September 2017 and June 2018.

\section{Data Analyses}

Vegetation attributes such as frequency, density, basal area (BA), relative frequency, relative density, relative dominance, and importance value index (IVI) [21] were calculated for each species. The Shannon-Wiener index $\left(\mathrm{H}^{\prime}\right)$ [3] and evenness index [7] were also calculated. The relationship between elevation and vegetation attributes (species richness, Shannon diversity, and total basal area) were evaluated using the simple linear regression analysis. The non-metric multidimensional scaling (NMDS) ordination technique was used to explore and visualize the ecological distances among these communities based on species occurrences (i.e., presence or absence). The NMDS analysis was implemented using the "metaMDS" function in the R-package "vegan" [28]. The "stressplot" was used to 
check the degree of fit between the ordination distance and the observed dissimilarity. The function "adonis" was used to test the group mean differences based on dissimilarities, and the "permutest" was used to evaluate the homogeneity of dispersions among the groups. All analyses were done using the R software package (version 4.0.3) [30].

\section{RESULTS}

\section{A. Plant Species Composition in the Togo Plateau Forest Reserve in Ghana}

A total of 281 plant species (164 trees, 60 saplings and 57 seedlings) belonging to 66 families were recorded from the study area (Table 1). These species included 4408 individuals from Bowuri (BO), 4066 Nkonya (NK), 3904 in Akpafu (AK), 3729 in Santrokofi (SA), 3605 in Hohoe (HH) and 3261 in Alavanyo (AL) portions of the Togo Plateau Forest Reserve. The trees stand per plot ranged from 20 to 69 , whereas saplings and seedlings numbered 11 to 38 and 8 to 30 , respectively, per plot.

Among the families recorded in the study, Leguminosae topped the list with IVI of $9.81 \%$ and 4100 individuals. This is followed by Apocynaceae, Euphorbiaceae and Malvaceae each of which recorded IVI of $4.00 \%$. Also, Rubiaceae and Sapindaceae recorded IVI of $3.38 \%$ each (Fig. 2). Family dominance showed a high degree of similarity among the study communities. This is evidenced from the dominance of the communities by the same set of families with Leguminosae being the most dominant in all cases (Fig. 2).

TABLE 1: GENERAL CHARACTERISTICS OF THE VEGETATION IN RELATION TO ELEVATION IN THE TOGO PLATEAU FOREST RESERVE IN GHANA

\begin{tabular}{|c|c|c|c|c|c|c|}
\hline Attribute & $\mathrm{BO}$ & NK & $\mathrm{AK}$ & SA & $\mathrm{HH}$ & $\mathrm{AL}$ \\
\hline Elevation (m a.s.1) & $200.18-631.59$ & $\begin{array}{l}\text { Combined } \\
205.97-632.83\end{array}$ & $241.52-669.75$ & $257.56-679.97$ & $262.52-694.35$ & $262.83-697.75$ \\
\hline Richness & 197 & 189 & 189 & 187 & 164 & 159 \\
\hline Number of individuals & 4408 & 4066 & 3904 & 3729 & 3605 & 3261 \\
\hline Number of families & 50 & 43 & 42 & 43 & 46 & 47 \\
\hline \multicolumn{7}{|c|}{ Trees } \\
\hline Richness & 114 & 107 & 107 & 106 & 85 & 83 \\
\hline Number of individuals & 1635 & 1551 & 1501 & 1453 & 1387 & 1318 \\
\hline Mean Shannon diversity index & 4.14 & 4.08 & 4.01 & 3.94 & 3.91 & 3.89 \\
\hline Mean Shannon evenness index & 1.00 & 0.95 & 0.94 & 0.93 & 0.93 & 0.92 \\
\hline Basal area $\left(\mathrm{m}^{2} / \mathrm{ha}\right)$ & 57.10 & 55.92 & 44.58 & 38.53 & 38.10 & 33.10 \\
\hline \multicolumn{7}{|c|}{ Saplings } \\
\hline Richness & 60 & 59 & 58 & 56 & 53 & 52 \\
\hline Number of individuals & 1496 & 1350 & 1300 & 1221 & 1193 & 1001 \\
\hline Mean Shannon diversity index & 2.74 & 2.74 & 2.71 & 2.60 & 2.60 & 2.56 \\
\hline Mean Shannon evenness index & 0.98 & 0.97 & 0.97 & 0.96 & 0.95 & 0.93 \\
\hline \multicolumn{7}{|c|}{ Seedlings } \\
\hline Richness & 41 & 41 & 38 & 38 & 37 & 25 \\
\hline Number of individuals & 1277 & 1165 & 1103 & 1055 & 1025 & 942 \\
\hline Mean Shannon diversity index & 1.74 & 1.69 & 1.67 & 1.64 & 1.62 & 1.59 \\
\hline Mean Shannon evenness index & 0.93 & 0.93 & 0.93 & 0.92 & 0.91 & 0.85 \\
\hline
\end{tabular}

Note: BO is Bowuri, NK is Nkonya, AK is Akpafu, SA is Sanko, AL is Alavanyo, HH is Hohoe.

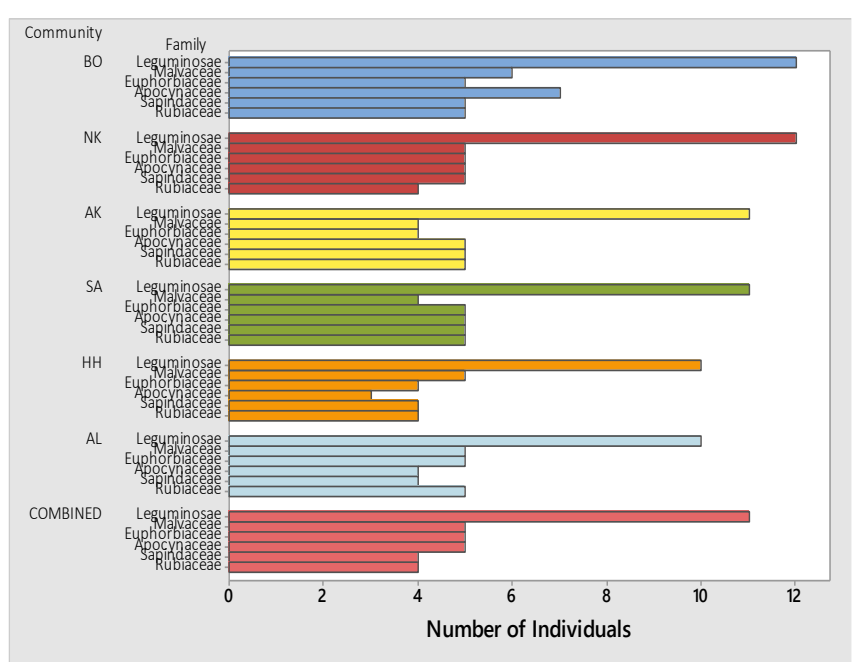

Fig. 2 Family dominance based on the relative importance value index (IVI, \%) compared for each of the studied communities and the whole of the landscape.

\section{B. Species Richness in the Togo Plateau Forest Reserve}

The species richness values recorded in the plateau ranged from 83-114 for trees, 52-60 for saplings and 25-41 for seedlings. BO recorded the greatest number of species of 197 (114 trees, 60 saplings and 41 seedlings) while AL had the least value of 159 ( 83 trees, 52 saplings and 25 seedlings) (Table 1). Among the trees, an overall average Shannon-
Weiner Index (H') of 3.99 was recorded, but values varied across the six communities (ranged from $4.14 \mathrm{~m}^{2} /$ ha at $\mathrm{BO}$ to $3.89 \mathrm{~m}^{2} / \mathrm{ha}$ at $\mathrm{AL}$ ). Evenness index across the communities, on the other hand, ranged from $1.00 \mathrm{~m}^{2} / \mathrm{ha}$ at $\mathrm{BO}$ to 0.92 $\mathrm{m}^{2} /$ ha at AL) with an average of 0.94 (Table 1).

Among the saplings, the average Shannon-Weiner Index (H') was calculated as 2.65 and varied across the six communities (ranged from $2.74 \mathrm{~m}^{2} /$ ha at $\mathrm{BO}$ to $2.52 \mathrm{~m}^{2} /$ ha at $\mathrm{AL})$. Whereas the calculated values of evenness index varied across the six communities (ranged from $0.98 \mathrm{~m}^{2} / \mathrm{ha}$ at $\mathrm{BO}$ to $0.93 \mathrm{~m}^{2} /$ ha at $\mathrm{AL}$ ) with an average of 0.96 (Table 1).

In the seedling category, the average Shannon-Weiner Index (H') was calculated as 1.66 and varied across the six communities (ranged from $1.74 \mathrm{~m}^{2} /$ ha at $\mathrm{BO}$ to $1.89 \mathrm{~m}^{2} /$ ha at $\mathrm{AL})$. Whereas $\mathrm{BO}, \mathrm{NK}$ and $\mathrm{AK}$ had the highest calculated values of evenness index as 0.98 , AL recorded the lowest value of 0.93 (Table 1).

The average basal area of trees was calculated as 44.72 $\mathrm{m}^{2} / \mathrm{ha}$ and varied across the six communities (ranged from $57.10 \mathrm{~m}^{2} /$ ha at BO to $33.10 \mathrm{~m}^{2} /$ ha at AL) (Table 1 ).

\section{Analysis of the Vegetation Structure of the TPFR}

1. Diameter distribution of trees, saplings, and seedlings in the TPFR

The trees, saplings and seedlings were grouped into six size-class distribution. The results showed that a greater 
number of individuals are in the lower diameter classes (DBH $10-100 \mathrm{~cm}$ ) in the TPFR with 3499 individual's ha-1 (Fig. 3). About 220 individual's ha- ${ }^{-1}$ are however, found in the upper diameter classes (DBH>100) (Fig. 3).

Notably, the distribution of individuals among the six communities studied was generally similar across the diameter classes (Fig. 3). Across nearly all diameter classes, BO recorded the greatest number of individual trees whilst $\mathrm{HH}$ had the least.

\section{The most important species in the TPFR}

The most important trees in the TPFR were $C$. pentandra $(\mathrm{IVI}=6.21 \%)$, A. zygia $(6.04 \%)$, T. superba $(4.89 \%)$, A. toxicaria $(4.37 \%)$ and $C$. gigantea (4.2\%; Table 2). These, species combined, accounted for $25.71 \%$ of the total IVI of all species in the study area. Eight other species recorded individual IVI values between $2.13 \%$ and $4.05 \%$, whereas the remaining species recorded less than $2 \%$ IVI on the landscape. The importance of the tree species varied somewhat across the communities, evidenced by different species dominating them. Although the six communities shared the 20 most abundant tree species on the landscape, $C$. pentandra was the most dominant in AK (IVI $=7.91 \%)$ and NK $(7.06 \%)$, whereas A. zygia was the most important species in $\mathrm{BO}$ (8.34\%), $\mathrm{HH}(7.29 \%)$ and $\mathrm{AL}(6.49 \%)$ respectively. The SA side of the reserve was, however, dominated by A. toxicaria with an IVI value of $6.90 \%$. (Table 2).

Among the saplings, A. camerunensis, M. puberula, $C$. ferruginea and E. calophylloides emerged the dominant species across the landscape, with respective IVI values of $8.91 \%, 3.18 \%, 3.13 \%$ and $3.09 \%$ (Table 3). It is noteworthy that these species were also the most important in each of the six communities studied.

In the seedling's category, $C$. odorata $(\mathrm{IVI}=29.55), P$. hirsuta $(\mathrm{IVI}=7.46)$, C. affer $(\mathrm{IVI}=6.04)$ and $H$. violacea $(\mathrm{IVI}$ $=5.83$ ) were the most dominant on the landscape (Table 4).
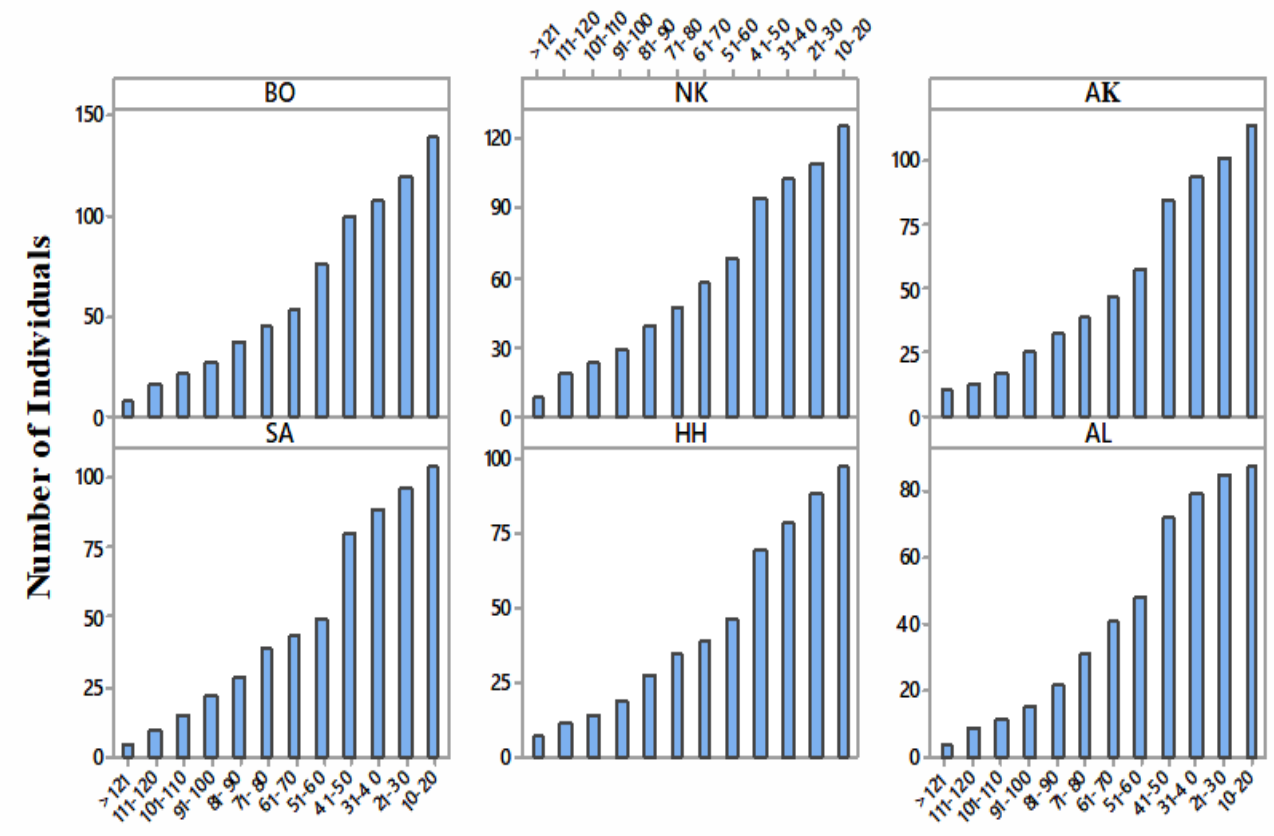

DBH Class (cm)

Fig. 3. Number of individuals recorded as a function of DBH Class attained in the TPFR in Ghana.

TABLE 2: RELATIVE IMPORTANCE VALUE INDICES (IVI, \%) OF THE 20 MOST IMPORTANT TREE SPECIES IN THE TPFR IN GHANA

\begin{tabular}{|c|c|c|c|c|c|c|c|}
\hline Trees & Combined & $\mathrm{BO}$ & $\mathrm{NK}$ & $\mathrm{AK}$ & SA & $\mathrm{AL}$ & $\mathrm{HH}$ \\
\hline Ceiba pentandra (L.) Gaertn. & 6.21 & 7 & 7.06 & 7.91 & 6.6 & 3.9 & 5.35 \\
\hline Albizia zygia (DC.) J.F. Macbr. & 6.04 & 8.34 & 4.67 & 3.74 & 5.3 & 6.49 & 7.29 \\
\hline Terminalia superba Engl. \& Diels & 4.89 & 1.61 & 7 & 6.38 & 4.56 & 5.45 & 4.6 \\
\hline Antiaris toxicaria Lesch. & 4.37 & 2.21 & 3.38 & 6.34 & 6.9 & 3.9 & 3.76 \\
\hline Cola gigantea A.Chev. & 4.2 & 5.52 & 3.88 & 7.55 & 2.92 & 1.36 & 4.79 \\
\hline Triplochiton scleroxylon K. Schum. & 4.05 & 5.14 & 5.17 & 4.94 & 3.29 & 2.8 & 3.32 \\
\hline Ficus capensis Thunb. & 3.87 & 2.26 & 3.78 & 2.64 & 3.34 & 6.02 & 4.79 \\
\hline Alstonia boonei De Wild. & 3.43 & 4.56 & 3.13 & 3.14 & 4.7 & 2.03 & 3.19 \\
\hline Sterculia tragacantha Lindl. & 3.34 & 3.46 & 3.61 & 4.44 & 1.81 & 3.54 & 3.29 \\
\hline Monodora myristica (Gaertn.) Dunal & 2.96 & 3.92 & 2.18 & 4.14 & 4.24 & 1.57 & 2.01 \\
\hline Funtumia elastica (Preuss) Stapf & 2.82 & 2.21 & 2.53 & 0.47 & 4.04 & 4.51 & 2.63 \\
\hline Bombax buonopozense P. Beauv. & 2.2 & 2.22 & 1.83 & 3.94 & 1.08 & 1.51 & 2.91 \\
\hline Distemonanthus benthamianus Baill. & 2.13 & 1.99 & 1.47 & 0.9 & 2.14 & 4.13 & 1.66 \\
\hline Canarium schweinfurthii Engl. & 1.99 & 1.46 & 2.76 & 1.27 & 1.6 & 3.36 & 1.22 \\
\hline Petersianthus macrocarpus (P. Beauv.) Liben & 1.62 & 3.2 & 3.8 & - & 0.27 & 1.03 & 1.44 \\
\hline Albizia ferruginea (Guill. \& Perr.) Benth. & 1.4 & 1.89 & 0.64 & 0.97 & 2.29 & 0.85 & 1.78 \\
\hline Dialium guineense Willd. & 1.4 & 1.88 & 0.23 & 1.84 & 1.41 & 0.51 & 2.69 \\
\hline Afzelia africana Sm. ex Pers. & 1.26 & 1.57 & 1.89 & 2.24 & 0.81 & 0.33 & 0.97 \\
\hline Irvingia gabonensis (Mildbr.) Okafor & 1.23 & 4.63 & 1.12 & - & 0.21 & 0.18 & 1.16 \\
\hline Nesogordonia papaverifera (A. Chev.) Capuron ex N. Hallé. & 1.21 & 1.56 & 0.71 & 1 & 2.16 & 1.41 & 0.28 \\
\hline
\end{tabular}


TABLE 3: RELATIVE IMPORTANCE VALUE INDICES (IVI, \%) OF 20 MOST IMPORTANT SAPLINGS IN THE TPFR IN GHANA

\begin{tabular}{cccccccc} 
Saplings & Combined & BO & NK & AK & SA & AL & HH \\
\cline { 2 - 7 } & IVI & IVI & IVI & IVI & IVI & IVI & IVI \\
\hline Acacia camerunensis Gand. & 8.91 & 7.9 & 9.16 & 12.92 & 9.43 & 6.31 & 7.88 \\
Microdesmis puberula Hook.f. ex Planch. & 3.18 & 3.46 & 3.81 & 3.04 & 3.26 & 2.37 & 3.34 \\
Cnestis ferruginea Vahl ex DC. & 3.13 & 4.81 & 3.11 & 3.52 & 1.66 & 2.26 & 3.49 \\
Eugenia calophylloides DC. & 3.09 & 4.75 & 5.82 & 1.00 & 1.42 & 3.23 & 3.11 \\
Hoslundia opposita Vahl & 3.06 & 3.46 & 2.30 & 2.54 & 4.67 & 1.94 & 3.18 \\
Pachystela brevipes (Baker) Baill. & 2.86 & 1.30 & 4.71 & 3.60 & 3.56 & 2.70 & 1.67 \\
Leucaena glaca (L.) Benth. & 2.79 & 1.73 & 2.50 & 1.72 & 3.12 & 3.45 & 4.40 \\
Bauhinia rufescens Lam. & 2.77 & 3.88 & 2.50 & 3.24 & 1.90 & 2.16 & 2.88 \\
Holarrhena floribunda (G. Don) T. Durand \& Schinz & 2.67 & 1.73 & 5.12 & 2.08 & 2.55 & 2.37 & 3.03 \\
Clausena anisata (Willd.) Hook.f. ex Benth. & 2.50 & 2.16 & 3.31 & 2.04 & 2.31 & 2.91 & 2.58 \\
Lonchocarpus cyanescens (Schum. \& Thonn.) Benth. & 2.46 & 1.36 & 1.10 & 2.28 & 3.06 & 4.69 & 1.67 \\
Dichapetalum madagascariense Poir. & 2.45 & 2.04 & 1.60 & 2.90 & 3.60 & 2.26 & 1.97 \\
Pavetta corymbosa (DC.) F.N. Williams & 2.42 & 4.63 & 0.90 & 3.68 & - & 1.51 & 3.49 \\
Mallotus oppositifolia (Geiseler) Müll.Arg. & 2.32 & 5.43 & 2.21 & 1.52 & 2.10 & - & 2.65 \\
Griffonia simplicifolia (DC.) Baill. & 2.31 & 1.48 & - & 3.14 & 4.01 & 2.26 & 2.35 \\
Annona senegalensis Pers. & 2.29 & 1.24 & 0.70 & 0.76 & 3.58 & 1.51 & 6.14 \\
Allophylus africanus P. Beauv. & 2.27 & 1.48 & 2.70 & 2.16 & 1.86 & 3.34 & 2.12 \\
Psychotria calva Hiern. & 2.18 & 2.84 & 2.91 & 0.64 & 2.93 & 1.62 & 2.43 \\
Olax subscorpioides Oliv. & 2.12 & 4.38 & 2.01 & 1.76 & 1.42 & 2.16 & 0.61 \\
Clerodendron umbellatum Ker Gawl. & 2.05 & 1.60 & 6.83 & 0.88 & 1.86 & 2.37 & - \\
\hline
\end{tabular}

TABLE 4: Relative IMPORTANCE VALUe INDiCes (IVI, \%) OF THE 20 Most DOMinANT SEEDLINGS IN THE TPFR, GHANA

\begin{tabular}{|c|c|c|c|c|c|c|c|}
\hline \multirow{2}{*}{ Seedlings } & Combined & $\mathrm{BO}$ & NK & $\mathrm{AK}$ & SA & AL & $\mathrm{HH}$ \\
\hline & IVI & IVI & IVI & IVI & IVI & IVI & IVI \\
\hline Chromolaena odorata (L.) R. King\& H. Rob. & 29.55 & 26.76 & 16.7 & 25.81 & 24.37 & 26.53 & 20.82 \\
\hline Palisota hirsuta (Thunb.) K. Schum. ex Engl. & 7.46 & 5.16 & 5.95 & 15.22 & 10.39 & 3.38 & 7.37 \\
\hline Costus affer Ker Gawl. & 6.04 & 2.48 & 4.71 & 13.81 & 10.17 & 4.72 & 5.03 \\
\hline Hypselodelphys violacea (Ridl.) Milne-Redh. & 5.83 & 6.09 & 8.92 & 10.92 & 1.79 & 7.42 & 3.8 \\
\hline Culcasia angolensis Welw. ex Schott. & 3.98 & 4.02 & 5.69 & 5.22 & 3.35 & 1.69 & 6.99 \\
\hline Adenia lobata (Jacq.) Engl. & 3.89 & 2.48 & 2.85 & 3.17 & 9.05 & 3.04 & 4.48 \\
\hline Panicum phragmitoides Stapf & 2.44 & 2.32 & 2.23 & 3.54 & 0.89 & 3.12 & 2.94 \\
\hline Caesalpinia benthamiana (Baill.) Herend. \& Zarucchi & 2.30 & 1.14 & - & - & 6.15 & 1.86 & 5.44 \\
\hline Andropogon gayanus Kunth & 2.22 & 2.36 & 3.68 & - & -- & 2.53 & 2.36 \\
\hline Tragia akwapimensis Prain & 2.22 & 5.16 & 1.24 & - & -- & 4.56 & 2.04 \\
\hline Chassalia kolly (Schumach.) Hepper & 2.08 & 1.34 & 3.10 & 1.49 & 7.71 & - & - \\
\hline Abrus precatorius $\mathrm{L}$. & 1.88 & 6.65 & 3.59 & - & 0.67 & - & 2.54 \\
\hline Commelina Africana $\mathrm{L}$. & 1.75 & - & 7.19 & 1.12 & -- & 3.88 & - \\
\hline Phaylopsis parviflora Willd. & 1.73 & 4.96 & 2.59 & - & 3.57 & 1.18 & 1.36 \\
\hline Piper guineense Schumach. \& Thonn. & 1.58 & 1.14 & 2.97 & - & 2.23 & 4.47 & - \\
\hline Emilia coccinea (Sims) G. Don & 1.44 & - & 4.47 & - & 2.01 & 2.45 & 1.36 \\
\hline Pennisetum purpureum Schumach. & 1.43 & - & 3.71 & - & 1.56 & 1.52 & 1.96 \\
\hline Landolphia micrantha (A. Chev.) Pichon & 1.40 & 1.14 & - & 5.51 & 1.34 & - & 0.58 \\
\hline Strophanthus sarmentosus DC. & 1.39 & - & 1.00 & - & 1.56 & 5.23 & - \\
\hline Oplismenus burmannii (Retz.) P. Beauv. & 1.05 & 1.91 & - & - & 2.35 & 1.69 & 1.16 \\
\hline
\end{tabular}

3. Species similarities and differences across the studied communities in the TPFR

The non-metric multidimensional scaling (NMDS) ordination analysis, based on species occurrences (i.e., presence or absence), showed a high degree of similarity in floristic composition among the studied communities (Fig. 4). This is evidenced in the pronounced overlap between the communities. In addition, permutation test of homogeneity of multivariate dispersion showed no significant differences $(p>$ $0.05)$ in the variances among the studied communities. Moreover, the degree of similarity was highest between the $\mathrm{BO}$ and NK than between the AL and NK.

\section{Elevation Effect on Species Distribution in the TPFR}

Regression analysis generally indicated strong influence (p $<0.05$ ) of elevation on the vegetation attributes of measured for trees across the studied communities (Table 5). The only exception to this was AK where no significant relations were observed between elevation and any of the vegetation attributes, and AL where Shannon diversity and evenness of trees were not strong associated with elevation. Basal area was also not correlated with elevation at NK and SA ( $p$ > 0.05). The saplings and seedlings generally exhibited a similar pattern. In terms of species distribution along the elevation gradient, the five most dominant tree species in the study area (i.e., C. pentandra, A. zygia, T. superba, A. toxicaria and $C$. gigantea) exhibited mid-elevation peak distribution pattern (Fig. 5). Majority of the species were within the 300-399 m elevation range, whereas the 600-699 $\mathrm{m}$ range recorded the least number of individuals of these species as expected.

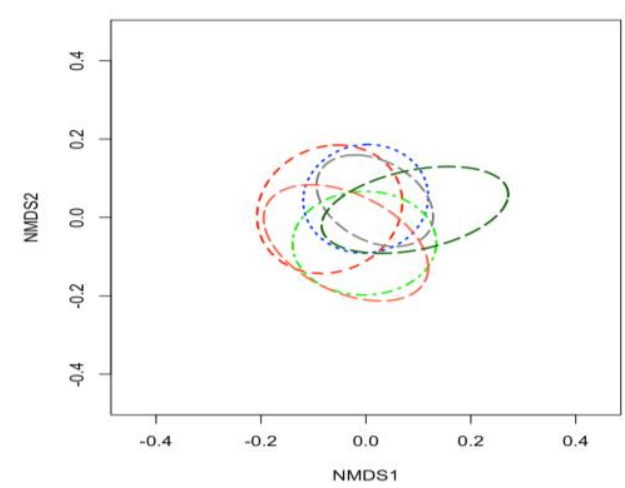

Fig. 4. Non-metric multidimensional scaling (NMDS) ordination of differences in floristic composition based on species occurrence (i.e., presence or absence) with respect to communities in the TPFR in Ghana. The following colours: red with broken lines, blue, gray, green, tomato, and dark green represents $\mathrm{BO}, \mathrm{NK}, \mathrm{AK}, \mathrm{SA}, \mathrm{HH}$ and $\mathrm{AL}$ respectively. 
TABLE 5: CORRELATION OF VEGETATION ATTRIBUTES WITH COMMUNITIES IN THE TPFR IN GHANA

\begin{tabular}{|c|c|c|c|c|c|c|c|c|c|c|c|c|}
\hline \multirow{2}{*}{ Attribute } & \multicolumn{2}{|c|}{$\mathrm{BO}$} & \multicolumn{2}{|c|}{ NK } & \multicolumn{2}{|c|}{$\mathrm{AK}$} & \multicolumn{2}{|c|}{ SA } & \multicolumn{2}{|c|}{$\mathrm{HH}$} & \multicolumn{2}{|c|}{$\mathrm{AL}$} \\
\hline & $\mathrm{r}$ & p-value & $\mathrm{r}$ & p-value & $\mathrm{r}$ & p-value & $\mathrm{r}$ & p-value & $\mathrm{r}$ & p-value & $\mathrm{r}$ & p-value \\
\hline \multicolumn{13}{|c|}{ Trees $(\mathrm{DBH} \geq 10 \mathrm{~cm}$, height $=1.3 \mathrm{~m})$} \\
\hline Average Elevation (m a.s.l) & \multicolumn{2}{|c|}{415.88} & \multicolumn{2}{|c|}{419.40} & \multicolumn{2}{|c|}{455.63} & \multicolumn{2}{|c|}{468.76} & \multicolumn{2}{|c|}{478.43} & \multicolumn{2}{|c|}{480.29} \\
\hline Richness & 0.48 & 0.008 & 0.50 & 0.005 & 0.08 & 0.672 & 0.59 & 0.001 & 0.64 & 0.00 & 0.41 & 0.024 \\
\hline Number of individuals & 0.59 & 0.001 & 0.48 & 0.007 & 0.09 & 0.647 & 0.68 & 0.00 & 0.58 & 0.001 & 0.36 & 0.05 \\
\hline Mean Shannon diversity index & 0.63 & 0.00 & 0.57 & 0.001 & 0.03 & 0.891 & 0.66 & 0.00 & 0.7 & 0.00 & 0.32 & 0.081 \\
\hline Mean Shannon evenness & 0.25 & 0.176 & 0.46 & 0.011 & 0.05 & 0.797 & 0.49 & 0.007 & 0.55 & 0.002 & 0.32 & 0.089 \\
\hline Basal area $\left(\mathrm{m}^{2} / \mathrm{ha}\right)$ & 0.49 & 0.006 & 0.3 & 0.103 & 0.03 & 0.854 & 0.27 & 0.142 & 0.4 & 0.029 & 0.46 & 0.011 \\
\hline \multicolumn{13}{|c|}{ Saplings $(\mathrm{DBH}<10 \mathrm{~cm}$, height $>1.5 \mathrm{~m})$} \\
\hline Richness & 0.53 & 0.002 & 0.46 & 0.01 & 0.17 & 0.366 & 0.48 & 0.007 & 0.75 & 0 & 0.18 & 0.181 \\
\hline Number of individuals & 0.63 & 0 & 0.39 & 0.033 & 0.06 & 0.75 & 0.56 & 0.001 & 0.62 & 0 & 0.43 & 0.017 \\
\hline Mean Shannon diversity index & 0.28 & 0 & 0.43 & 0.017 & 0.1 & 0.582 & 0.47 & 0.009 & 0.56 & 0.001 & 0.36 & 0.054 \\
\hline Mean Shannon evenness & 0.62 & 0 & 0.16 & 0.406 & 0.01 & 0.971 & 0.47 & 0.009 & 0.57 & 0.001 & 0.27 & 0.146 \\
\hline \multicolumn{13}{|c|}{ Seedlings $(\mathrm{DBH}<3 \mathrm{~cm}$, height $<1.5 \mathrm{~m})$} \\
\hline Richness & 0.6 & 0 & 0.1 & 0.604 & 0.32 & 0.085 & 0.84 & 0 & 0.6 & 0 & 0.15 & 0.44 \\
\hline Number of individua & 0.48 & 0.008 & 0.52 & 0.003 & 0.03 & 0.863 & 0.63 & 0 & 0.59 & 0.001 & 0.46 & 0.011 \\
\hline Mean Shannon diversity index & 0.6 & 0 & 0.45 & 0.012 & 0.13 & 0.495 & 0.7 & 0 & 0.63 & 0 & 0.33 & 0.073 \\
\hline Mean Shannon evenness & 0.73 & 0 & 0.54 & 0.002 & 0.12 & 0.536 & 0.26 & 0.159 & 0.71 & 0 & 0.28 & 0.131 \\
\hline
\end{tabular}

Bold means regression was insignificant at $5 \%$ level.

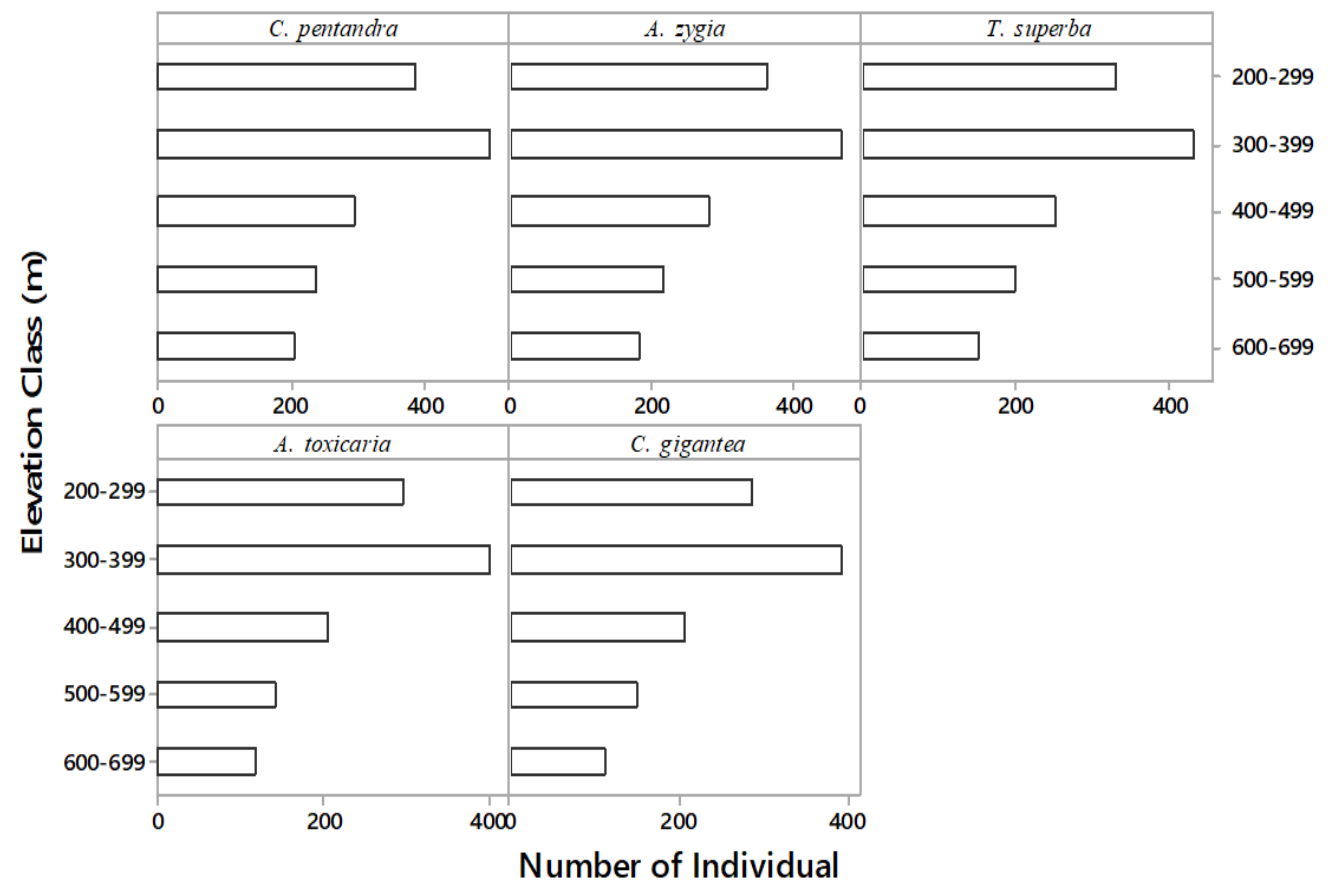

Fig. 5. Species dominance by number of individuals with respect to elevation in the TPFR in Ghana.

\section{IV.DISCUSSION}

\section{A. Plant Species Composition in the Togo Plateau Forest Reserve in Ghana}

The overall plant diversity in the TPFR (281 in ca. 11.4 ha), was higher compared with studies from similar ecosystems in Ghana. For example, 176 woody plant species were recorded in ca. 1.9 ha in the Afadzato Community Forest Conservation Area and 142 plant species in a 2.4 ha area of the Atiwa Range Forest Reserve and 120 plant species in a 2 ha section of the Kade forest [22]-[20]. Other tropical forests, however, recorded a much higher species richness of over 300 per hectare in Ghana [26] and elsewhere [3], [5], [7], [12]. The high species diversity observed in the TPFR agrees with several studies that plateau ecosystems are one of the most ecologically complex and biologically rich ecosystems in the world [3]-[5] and that they provide a series of elevation gradients that drive the patterns of species composition and structure [8], [5], [15].
All the plant growth forms were identified in the 180 plots distributed throughout the TPFR in Ghana. The discovery of Leguminosae, Euphorbiaceae, Apocynaceae and Malvaceae as the most dominant plant families is not surprising as this is typical of tropical forests in Ghana [22], [26] and elsewhere [1], [17], [22]-[35]. These families are also the most important and well distributed across the six communities studied, an indication of their wide ecological amplitude and tolerance of diverse environmental conditions [17]. This result also suggests that tropical forests throughout the world showed much similarity at the family level [17], [23], and a prove of maturity as these families are generally represented by woody species [17], [23].

\section{B. Species Diversity in the Togo Plateau Forest Reserve}

Tree species richness and diameter class distribution in a defined ecologically hotspot gives a reliable instrument to indicate the diversity level [3]-[5]. The average ShannonWeiner Index (H') (which is more sensitive to species richness) and evenness index for trees $(3.99,0.92)$ recorded 
in the study were higher than studies from similar ecosystems in Ghana including the Kade forest (2.37, 0.86; [20]), Afadzato Community Forest Conservation Area (2.24, 0.85; [21]) and Atiwa forest $(2.65,0.84 ;[20])$ and elsewhere (3.2, $0.58 ;[15])$. The recorded values in this study were, however, lower than other similar studies including (4.05, 0.98; [23]) and (4.02, 0.96; [18]). Saplings and seedlings also follow a similar pattern in composition and structure. The high diversity of species recorded in the study suggests that the TPFR was not seriously disturbed by anthropogenic and ecological factors.

Across the study communities, Shannon-Weiner Index (H') and evenness index for trees varied (ranged from 4.14 at $\mathrm{BO}$ to 33.89 at $\mathrm{AL}$ ) and (ranged from 1.00 at BO to 0.92 at $\mathrm{AL}$ ), an indication of elevation gradient effect between the communities. Saplings and seedlings diversity and evenness index also followed a similar pattern. However, these results from the communities fall within the ranges of (2.00 to 4.86) and $(0.21$ to 1.00$)$ reported in tropical forests in Ghana [20], [21], [22] and elsewhere [15], [17], [23]. These results showed that each community is very diverse, stable and well adapted [17], [23]. Probable causes for the local variations in species composition and structure among the communities include the geographical locations of these communities which somehow correspond with different elevations to the plateau (i.e., BO, NK occur in lower and gentle elevations, $\mathrm{AK}, \mathrm{SA}$ in mid elevation and $\mathrm{HH}, \mathrm{AL}$ in higher elevations with rocky and varied inclined slope areas). The BO and NK communities lie on lower elevations and generally receive lower solar radiation flux density resulting in lower evapotranspiration rates, lower daily maximal temperatures, and better soil types and thus, tend to be more humid, cooler and productive [1], [3], [4], [21], giving a higher habitat diversity [3], [6]. On the other hand, $\mathrm{HH}$ and AL lie on higher elevation and appeared to be receiving more solar energy resulting in low soil moisture content, higher transpiration rates and a reduction in plant growth [1], [3], [4], [21], giving a lower habitat diversity [3], [6].

The other factor accounting these slight differences in patterns of vegetation composition and structure among the communities in the TPFR could be utilization pressure [1]. The $\mathrm{HH}$ and AL communities have more traditional medicine practitioners, hence the rate of exploitation of plant materials from their portion of the plateau for traditional medicinal activities was higher than the other communities [19], [26]. These portions have also seen aggressive logging of $C$. pentandra and other woods to meet the timber needs of a recently established plywood factory in the area [1], [4], [19].

Basal area of trees (BA) provides a parameter that compare vegetation structure and quality [17]. The average basal area of $44.72 \mathrm{~m}^{2} \mathrm{ha}^{-1}$ recorded in this study across the six communities was greater than that recorded in the Kade forest $\left(30.85 \mathrm{~m}^{2}\right.$ ha-1; [20]), Afadzato Community Forest Conservation Area (35.13 $\mathrm{m}^{2} \mathrm{ha}^{-1}$; [21]), Atiwa forest (30.25 $\mathrm{m}^{2} \mathrm{ha}^{-1}$; [19]) all of Ghana, the tropical deciduous forests of Northcentral Eastern Ghats, India $\left(28.42 \mathrm{~m}^{2} \mathrm{ha}^{-1}\right.$; [23]), Deosai Plateau (30.27 $\mathrm{m}^{2} \mathrm{ha}^{-1}$; [29]), Andean forests $\left(33.90 \mathrm{~m}^{2} \mathrm{ha}^{-1}\right.$; [16]). Other studies have recorded a higher basal area than TPFR including dry evergreen forest of Kondapalli (Andhra Pradesh state, India) (47.17 m2 ha-1; [15]), Amaggal Reserve Forest (53.33 $\mathrm{m} 2$ ha- $^{1}$; [28]) and
Mizoram-Manipur-Kachin rainforest $\left(54.31 \mathrm{~m}^{2} \mathrm{ha}^{-1}\right.$; [17]). In general, the observed high species richness, Shannon diversity and basal area in the TPFR agrees with several reports that plateau ecosystems are species rich and very productive [1]-[5]. In the present study, the basal area of trees varied across the six communities (ranged from $57.10 \mathrm{~m}^{2} / \mathrm{ha}$ at $\mathrm{BO}$ to $33.10 \mathrm{~m}^{2} / \mathrm{ha}$ at $\mathrm{AL}$ ). This variation may be attributed to varied environmental variables associated with elevation effect (i.e., wetter, or drier slopes, soil properties) [16]. However, the general high basal area values seen in all the communities gives an indication that the stand structure of the whole of the plateau is healthy [15].

\section{Analysis of the Vegetation Structure of the TPFR \\ 1. Diameter distribution of trees, saplings, and seedlings in the TPFR}

The DBH evaluation reflects the evidence of disturbance and resource usage by species in forest ecosystems [15]. In the TPFR, many species (3499 individual's ha-1) were present only as small individuals with diameters $10-100 \mathrm{~cm}$ DBH (Fig. 4 and 6), which was in accordance with the findings from several plateau forests [15], [17], [23] an indication that the plateau is harbouring a growing and healthy vegetation, and the site resources are being utilized to the maximum [17], [23]. The DBH, however, revealed a similar vegetation distribution across the study communities [16], [18].

\section{The most important species in the TPFR}

Importance Value Index (IVI) is computed for species or family with the aim of comparing their ecological significance in a given forest type [19], [21], [22]. A high IVI gives an indication that the species sociological structure in the community is high [15]. Plant species having similar IVI should automatically have similar stand composition and structure, environmental stress, site requirements, and comparable dynamics [13]. The leading dominant and ecologically most significant trees, saplings and the seedling on the landscape were $C$. pentandra, A. zygia, $A$. camerunensis, $S$. krauseaena respectively. These dominance of these species in the Togo Plateau landscape might be associated with their regeneration success, pathogen resistance, shade tolerance, and aggressive growth, optimal resource use and dispersal mechanism, while being the least preferred by browsing animals and disturbance stress [28]. Interestingly, all the communities had wide distribution of these species and may reflect their tolerance of wide ecological conditions [18].

3. Species similarities and differences across the studied communities in the TPFR

The results showed that the vegetation composition and structure was similar across all the study communities except AL which was quite distinct (Fig. 3, Table 5). The highest similarity was seen between $\mathrm{BO}$ and NK, suggesting that the two communities have similar vegetation requirements [18]. The distinct composition of AL from the rest of the communities may be due to its different altitude and associated environmental conditions which affect species growth and survival [18]. In fact, all the study plots from AL were located at higher altitudes than plots in the other communities.

\section{Elevation Effect on Species Distribution in the TPFR}

The six most important tree species listed on the landscape 
were distributed along a broad range of elevation. These species have demonstrated an increase in composition and structure with altitude until mid-elevations and then decreases as expected in tropical forests [16]. As documented, rainfall and temperature decreased with elevation, meaning that forest at lower elevations were subjected to wetter and warmer conditions that favours plant growth [18]. In general, the results posit a strong influence of elevation gradient on vegetation attributes in the TPFR.

\section{REFERENCES}

[1] Bhandari, J., and Y. Zhang. (2019). Effect of altitude and soil properties on biomass and plant richness in the grasslands of Tibet, China, and Manang District, Nepal. Ecosphere 10(11): e02915. 10.1002/ecs2.2915.

[2] Carrick P. J., Forsythe K. J. (2020) The species compositionecosystem function relationship: A global meta-analysis using data from intact and recovering ecosystems. PLoS ONE 15(7): e0236550.https://doi.org/10.1371/journal. pone.0236550.

[3] Nikolay M. Luna-Kamyshev, Jorge Omar Lopez-Martınez, Benedicto Vargas-Larreta, Gerald Islebe1, Tulio F. Villalobos-Guerrero, Andres Va 'zquez de la Rosa, Oscar F. Reyes-Mendoza\& Eduardo Trevi noGarza (2020) Floristic Composition, Diversity, and Biomass of a Protected Tropical Evergreen Forest Belize.Tropical Conservation Science Volume 13: 1-13.

[4] Sainge, M. N., Lyonga, N. M., Mbatchou, G. P. T., Kenfack, D., Nchu, F. \& Peterson, A. T., (2019) 'Vegetation, floristic composition and structure of a tropical montane forest in Cameroon', Bothalia 49(1), a2270. https://doi.org/10.4102/abc.v49i1.2270.

[5] Zhang B, Zhang H, Jing Q, Wu Y, Ma S (2020) Differences in species diversity, biomass, and soil properties of five types of alpine grasslands in the Northern Tibetan Plateau. PLoS ONE 15(2): e0228277.https://doi.org/10.1371/ journal. pone. 0228277.

[6] Mengistu Teshome, Zebene Asfaw \& Gemedo Dalle (2020) Effect of environmental gradients on diversity and plant community distribution in remnant dry Afromontane forest of Mount Duro, Nagelle Arsi, Ethiopia Biodiv. Res. Conserv. DOI 10.2478/biorc-2020-0004.

[7] Neri A. V, Rodrigues A. C, Villa P. M, Ali A \&Ferreira-Junior W (2019) Fine-scale habitat differentiation shapes the composition, structure and aboveground biomass but not species richness of a tropical Atlantic forest. J. For. Res. http://www.springerlink.com.

[8] Xu WH, Xiao Y, Zhang JJ, Yang W, Zhang L, Hull V, Wang Z, Zheng H, Liu JG, Polasky S, Jiang L, XiaoY, Shi XW, Rao EM, Lu F, Wang XK, Daily GC, Ouyang ZY (2017) Strengthening protected areas forbiodiversity and ecosystem services in China. Proceedings of the National Academy of Sciences of theUnited States of America 114: 1601-1606. https://doi.org/10.1073/pnas.1620503114 PMID: 28137858.

[9] Costanza R, Groot RD, Braat L, Kubiszewski I, Fioramonti L, Sutton P, Farber S, Grasso M (2017) Twenty years of ecosystem services: How far have we come and how far do we still need to go? EcosystemServices 28: $1-16$.

[10] Joshi AK, Joshi PK (2018) Forest Ecosystem Services in the Central Himalaya: Local Benefits and Global Relevance. Proceedings of the National Academy of Sciences India: 1-8.

[11] Wu D, Zou C, Cao W, Xiao T, Gong G (2019) Ecosystemservices changes between 2000 and 2015 in the Loess Plateau, China: A response to ecological restoration. PLoS ONE 14(1): e0209483.https://doi.org/10.1371/journal. pone.0209483.

[12] Sumasgutner P, Terraube J, Aurélie Coulon A, Villers A, Chakarov N, Kruckenhauser L\& Korpimäki E. (2019) Landscape homogenization due to agricultural intensification disrupts the relationship between reproductive success and main prey abundance in an avian predator. Frontiers in Zoologyhttps://doi.org/10.1186/s12983-019-0331-z.

[13] Todou G, Dedangsou S \& Kémeuzé A. (2017) Floristic composition, diversity and ecological importance of woody plants in eastern part of National Park of Sena Oura, Chad. Journal of Biodiversity and Environmental Sciences (JBES) ISSN: 2220-6663.

[14] Navarro-Martınez, A., Ellis, E. A., Herna'ndez-G_omez, I., RomeroMontero, J. A., \& Sa'nchez-Sa'nchez, O. (2018). Distribution and abundance of big-leaf mahogany (Swietenia macrophylla) on the Yucatan Peninsula, Mexico. Tropical Conservation Science, 11, 1-17.

[15] Prasad P. R. C\& Kumari J. A (2019) Structure, composition and diversity of trees within the dry evergreen reserve forest of Kondapalli (Eastern Ghats, southern India) Biodiv. Res. Conserv. DOI 10.2478/biorc-2019-0009.
[16] Malizia A, Blundo C, Carilla J, Osinaga Acosta O, Cuesta F, DuqueA, et al., (2020) Elevationand latitude drives structureand tree species compositionin Andean forests: Results from a large-scale plot network. PLoS ONE 15(4): e0231553. https://doi.org/10.1371/journal.pone.0231553.

[17] Gogoi A, Sahoo U. K \& Hemanta Saikia H (2020) Vegetation and ecosystem carbon recovery following shifting cultivation in MizoramManipur-Kachin rainforest eco-region, Southern Asia.Ecological Processes https://doi.org/10.1186/s13717-020-00225w.

[18] Yirga F, Marie M, Kassa S \& Haile M (2020) impact of altitude and anthropogenic disturbance on plant species composition, diversity and structure at the Wof-Washa highlands of Ethiopia.Elsevier Ltd. (http://creativecommons.org/licenses/by/4.0/).

[19] Dogor G. F. K, Nyarko R. A, Anning A. K \& Oteng-Yeboah A (2018) Medicinal plant use and conservation practices by communities in the Togo Plateau Forest Reserve, Ghana. Journal of Medicinal Plants Research Vol.12(30), pp.575-589.

[20] Swaine M.D, Hall J.B, \& Alexander I.J (1982). Tree population dynamics at Kade Foest, Ghana. Department of plant science, The University, Aberdeen AB9 2UD, Scotland.

[21] Dogor G. F. K, Anning A. K \& Oteng-Yeboah A (2019) Plant Diversity and Distribution Patterns in a Tropical Mountain Forest in Ghana. Journal of Ghana Science Association, Vol. 18, No. 2

[22] Amandine Erktan, M. Luke McCormack \& Catherine Roumet. (2018) Frontiers in root ecology: recent advances and future challenges. Springer International Publishing AG.

[23] Naidu M. T, Premavani D, Suthari S\& Venkaiah M (2018) Assessment of tree diversity in tropical deciduous forests of Northcentral Eastern Ghats, India, Geology, Ecology, and Landscapes, 2:3, 216-227, DOI: 10.1080/24749508.2018.1452479.

[24] Premavani D, Tarakeswara M. N, Aniel Kumar O \& Venkaiah M. (2017) Diversity and distribution of tree species in tropical forests of Northcentral Eastern Ghats, IndiaASIAN Journal of Forestry. DOI: 10.13057/asianjfor/r010104.

[25] Sun C, Chai Z, Liu G and Xue S (2017) Changes in Species Diversity Patterns and Spatial Heterogeneity during the Secondary Succession of Grassland Vegetation on the Loess Plateau, China. Front. Plant Sci. 8:1465. doi: 10.3389/fpls.2017.0146.

[26] Addo-Fordjour P, Anning AK, Belford EJD, Akonnor D (2013) Diversity and conservation of medicinal plants in the Bomaa community of the BrongAhafo region, Ghana. Journal of Medicinal Plants Research 2 (9):226-233.

[27] Hamayun Shaheen, Muhammad Ibrahim\& Zahid Ullah (2019) Spatial patterns and diversity of the alpine flora of Deosai Plateau, Western Himalayas. Pak. J. Bot., 51(1): 205-212.

[28] Paula Nieto-Quintano, Edward T. A. Mitchard, Roland Odende, Marcelle A. Batsa Mouwembe, Tim Rayden, and Casey M. Ryan (2018). The mesic savannas of the Bateke Plateau: carbon stocks and floristic composition. BIOTROPICA 50(6): 868-88.

[29] GHANA METEOROLOGICAL AGENCY: Agro meteorological

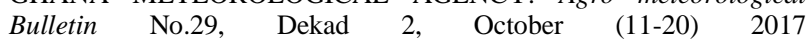
GMET/AGROMET/111017FORM 910.

[30] R Core Team, R (2018): A language and Snvironment for statistical Computing. R Foundation forStatistical Computing, Vienna, Austria. http://www.R-project.org. 